\title{
A STUDY ON STUDENTS' ABILITY IN READING DESCRIPTIVE TEXT; A CASE STUDY AT SMAN 1 SIKUR
}

\author{
${ }^{1}$ Ahmad Zuhri Rosyidi, ${ }^{2}$ Darmanto \\ ${ }^{1}$ English Lecturer, Institut Pendidikan Nusantara Global, Indonesia \\ ${ }^{2}$ English Lecturer, Universitas Samawa, Indonesia \\ Corresponding Author Email: rosyidiahmad08@gmail
}

\begin{tabular}{ll}
\hline \hline Article Info & Abstract \\
Article History & This study was intended to find out the students' ability in reading descriptive \\
Received: June 2020 & text. Reading skills are considered as an important skill and are uneasy to \\
Revised: July 2020 & acquire. In this study, there were 40 students of the second year students of \\
Published: July 2020 & SMAN 1 Sikur are involved as the subject of this study. The method used in this \\
Keywords & research is a quantitative study. In collecting the data, the writer used a reading \\
Descriptive text; & test. The data were analyzed through basic statistical computation. To find out \\
Reading skills; & their ability and difficulties in reading descriptive text, the test was used which \\
& consists of 25 items to students in the form of multiple choice. The test score for \\
& each item was 0.4 points. The result of data analysis showed that the mean score \\
& of the second year students of SMAN 1 Sikur in reading the descriptive text was \\
fairly good. There were 21 (52.5\%) students who were in a high position and 19 \\
(47.5\%) students were in a low position. Although $52.5 \%$ of students in a high \\
position and $47.5 \%$ in a low position, the students' mean score shows a low \\
position, it is 7.2 mean score which classified as fairly good. Therefore, the \\
ability of the second year students of SMAN 1 Sikur has not been in a high \\
position which is categorized from excellent to good score level. This is caused \\
by the lack of reading strategy and vocabulary. The two weaknesses become \\
students' difficulties in reading descriptive text.
\end{tabular}

How to cite: Rosyidi, A. Z., \& Darmanto. (2020). A study on students' ability in reading descriptive text; A case study at SMAN 1 Sikur. JOLLT Journal of Languages and Language Teaching, 8(3), 330-335, DOI: https://doi/org/10.33394/jollt.v\%vi\%i.2723

\section{INTRODUCTION}

English is one of the international languages, which is used as a means of communication among people all over the world either in a formal or informal situation. In some countries like America, England, and Australia, people speak English as their mother tongue. It is different from other countries like Indonesia, India, and the Philippines, people use English as a foreign language (Bolton, 2019; Haerazi \& Irawan, 2020). Since the English language becomes very important in daily lives, the enthusiasm or interest of people in learning it drastically increases. The problem face by EFL students is that they are uneasy to acquire vocabulary to function in reading English texts (Haerazi \& Irawan, 2020b).

In learning English in Indonesian schools, some skills should be mastered by students. Those are speaking, reading, listening, and writing (Haerazi et al., 2019). One of the English skills that can improve other skills is reading (Nerim, 2020). According to Troyer et al. (2019) reading is a process of understanding a written language or text. From the reading activity, students can get information and support their writing, speaking, and listening skills because it can acquire vocabulary, grammar, and discourse markers (Rohmah, 2018; Ambarini et al., 2018). By the reading, the knowledge of the students is gradually increased and it may cause other language skills are developed such as listening, speaking, and writing. In addition, the 
knowledge and experience obtained from reading can make wide intellectual abilities (Aziz et al., 2019). Furthermore, reading activity provides the language input, the same as listening. This fact shows that the teaching of reading is important to get attention seriously and reading is not only looked as a stir to speaking and writing activities should be developed every time.

In some ELT studies, reading skills are very crucial for students to develop other language skills. Unfortunately, English teachers still do not have enough competences to choose an appropriate learning strategy to improve students' reading comprehension (Imran et al., 2019). Teaching reading aims to develop the student's reading skills so that they can read more effectively and efficiently. Readers should have a particular purpose in their minds before they interact with text (Lail, 2019). According to Williams (1984) and Hidayat (2017), the purpose of reading is classified into getting general information from the text; getting specific information from a text, and reading for pleasure or interest. The students are expected to be able to use the language through reading, listening, speaking, and writing. In fact, reading should be handled seriously, because reading is one of the skills, which is very important to be developed.

Nowadays, in order to comprehend the text easily, Indonesian students have to master a number of English vocabulary items. Many graduates of SMA/MA do not understand English text well. This is caused by the lack of vocabulary items, the lack of knowledge, grammar and other language components. Then, to enable them to understand the English text, the teaching of vocabulary should be developed. In this case, the teacher is considered as a model, moderator, facilitator of knowledge in the teaching-learning process and this matter is necessary to develop i.e. English, especially English reading comprehension. Based on the phenomenon above, this research is intended to investigate the second-year students' ability of SMAN 1 Sikur in the academic year 2019 in reading descriptive text.

\section{RESEARCH METHOD}

\section{Research Design}

Descriptive quantitative research was used in this research. According to Sugiyono (2012: 13) descriptive research is, research conducted to determine the value of independent variables, either one or more variables (independent) without making comparisons or connecting with other variables.

\section{Population and Sample}

The population of this study is the whole second-year students of SMAN 1 Sikur in the academic year 2019/2020. The population is the whole object of research (Arikunto. 2006: 130). They are divided into 8 classes, and the total numbers of the students about 311 students. The research is only focused on second-grade students in the academic year 2019/2020. The large sample has more a mounting possibility to become the representative for its population. Despiteful, by large sample, the data become more accurate and more precious. If the population was less than 100, it would be better to take all of them as a sample of the study and if the population more than 100, it would be better to reduce for $10-15 \%$ or $20-25 \%$ or more. In this study, the writer takes $13 \%$ of the population as the sample (Arikunto, 2010). So the writer took 40 students as the sample of this research.

\section{Instruments}

The instrument used to collect the data in this study is an ability test. After finishing each of the tests, then the research collects and manually. The ability test, which constructed in multiple choices, is not so difficult to score for the students are only required to write down their answer sheet provides. The total of reading text is 25 questions in the form of multiple choices. The test weight for each item is 0.4 points, so the highest students' score is 9.6-10 which classified as excellent and the lowest score is $0.0-3.5$ as very poor in the position. 


\section{Data Analysis}

To obtain the data needed for this particular present study. The writer simply needs to ask the student. Firstly, read to the passage in a different topic on two separate time allotment. Secondly, the students answer the question concerning the text individually. The samples of students result in the impact of this research. To get the actual data from the test held out several steps bellow are done accordingly. The students are asked to read the text and answer the question based on the texts and the texts are provided into two passages, the total of reading text is 25 questions in the form of multiple choices.

In this research, the writer uses a descriptive method from the objective test or reading test to analyze and find out the student's ability. The result of the test tabulated to find out the means score by applying the mean computation formulation. The number of student's in various positions includes the score of 9.6-10 is classified as excellent, the 8.6-9.5 is classified as very good, the score of 7.6- 8.5 is classified as good, the score of 6.6- 7.5 is classified as fairly good, the value of 5.6- 6.5) is classified as fair, the value of 3.6- 5.5 is classified as poor, and the score of 0.0-3.5 is classified as very poor. In this study, the "Fairly good" score to very poor levels are classified as low while the term 'excellent to good score level' is classified as high.

\section{RESEARCH FINDINGS AND DISCUSSION Research Findings}

This part deals with the data analysis of students' ability in reading descriptive text at the second-year students of SMAN 1 Sikur, which focused to observe the students' answers and scores. The data analysis in this research was presented by using descriptive analysis. The instrument was used in this research is a descriptive text test in the form of multiple choice. To get a rather explanation that how the score tabulated into the rate of percentage. The writer categorized their score into seven levels. The students' score after getting the test are 1 student achieved 25 (10), 7 students got 24 (9.6), 3 students got 23 (9.2), 3 students got 22 (8.8), 1 student got 21 (8.4), 2 students got 20 (8.0), 4 students got 19 (7.6), 2 students 18 (7.2), 3 students got 17 (6.8), 2 students got 16 (6.4), 3 students got 15 (6.0), 1 student got 14 (5.6), 3 students got 13 (5.2), 3 students got 12 (4.8), 1 student got 8 (3.2), and finally 1 student got 7 (2.8).

From the score above the percentage of students' answers in the objective test can be shown in the following table.

Table 2: Rate of the students' score through an objective test

\begin{tabular}{llcccc}
\hline No & Classification & Score & $\begin{array}{c}\text { Correct } \\
\text { answer }\end{array}$ & $\begin{array}{c}\text { Number of } \\
\text { students }\end{array}$ & Percentage \\
\hline 1 & Excellent & $9.6-10$ & $24-25$ & 8 & $20 \%$ \\
\hline 2 & Very good & $8.6-9.5$ & $22-23$ & 6 & $15 \%$ \\
\hline 3 & Good & $7.6-8.5$ & $19-21$ & 7 & $17.5 \%$ \\
\hline 4 & Fairy good & $6.6-7.5$ & $17-18$ & 5 & $12.5 \%$ \\
\hline 5 & Fairy & $5.6-6.5$ & $14-16$ & 6 & $15 \%$ \\
\hline 6 & Poor & $3.6-5.5$ & $9-13$ & 6 & $15 \%$ \\
\hline 7 & Very poor & $0.0-3.5$ & $0-8$ & 2 & $5 \%$ \\
\hline & & & & 40 & $100 \%$ \\
\hline
\end{tabular}


Fairly good to very poor levels score is classified as a low score, excellent to good score levels are classified as a high score. Based on Table 2, the students got (9.6-10) score consist of 8 students which are classified as excellent. While students got (8.6-95) score is 6 students that classified as very good, and 7 students got (7.6- 8.5) as a good score. In the other side, the students got (6.6- 75) score is 5 students as fairly good, 6 students got (5.6- 6.5) score as fair, 6 students got (3.6- 5.5) as poor. Finally, there are only 2 students got (0.0- 3.5) score as a very poor position. The result shows that the mean score of the students is 7.2 score. So, it could be classified as a Fairly Good position.

\section{Discussion}

In the learning-teaching process, students applied some reading strategies such as students to try understanding any individual words to comprehend the meaning of sentences. In this situation, the English teacher provides students with a vocabulary list. It is aimed at helping students who do not know the meaning of difficult words. To train students to comprehend texts, the teacher provided them with familiar texts. This study showed that students still have difficulties to catch the comprehension from simple texts. It is because of a lack of vocabulary acquisition. It is line with Hanifah and Afidah (2018) who state that the serious problems faced by English learners in the reading process are a lack of vocabulary acquisition. Because of this, teachers should give students useful strategies to read.

In this study, the researchers provided some reading texts to see the students' reading comprehension level. The text consisted of three pages with 25 items, while the sample in this research was 40 students. So, the total of questions for all students was 1000 items. The students were able to answer the question correctly only 723 items, while 277 questions were the false answer. It is clear that most of the questions of this testability were answered correctly by the second year students of SMAN 1 Sikur in the academic year 2019/2020. Based on the result of the research, there were $8(20 \%)$ students in an excellent position, there were $6(15 \%)$ students in very good, there were $7(17.5 \%)$ students in a good level, there were $5(12.5 \%)$ students in fairly good, there were $6(15 \%)$ students in fair, there were $6(15 \%)$ students in poor, and there were $2(5 \%)$ students is in very poor. These data showed that most students need to provide various genres in order that they can acquire much more vocabulary. The teacher needs to involve them in much more reading activities. It is in accordance with Hartatik and Lestari (2016) who inform that reading experiences for students are essential to improve their reading comprehension.

Through the result, the writer classified 21 students as high, and 20 students classified as low. There are $52.5 \%$ of students were able to answer 19 or more questions correctly and $47.5 \%$ could only answer less than 19 questions correctly. If the students could answer questions 19 or more, they could be classified as high and less than that is in a low position. Fairly good to very poor level scores were classified as low, while excellent to a good level were classified as high. So, the result indicated that the second-year students of SMAN 1 Sikur were still in a low position because from the students' mean score obtained 7.2 score which is in a fairly good position. The data showed that students still have difficulties to identify the main idea of each paragraph. The problems here are that students do not understand some sentences of the paragraph because the generic patterns of the text present high grammatical patterns. It is in accordance with Khatimah and Rachman (2018) who inform that students in reading activities always face problems identifying the textual content because of low knowledge of grammatical competences. The lack of grammatical knowledge is caused by students' reading experiences (Indrasari et al., 2018).

The problem answers of the student were found is most of the questions could answer by the students correctly (723 items) than the false one (277 items). This is relevant to the data finding that the students' ability was in a fairly good position. The results of this study have not made the second-year students of SMAN 1 Sikur at a high level, because the average 
of students was 7.2, this rate involved in a low position. The writer found students' difficulties in this study. Some students have not known the strategy of reading tests yet. For an instant, reading fast or skimming and scanning. This is the weakness of students that made them difficult to answer the question. Some students still very poor in vocabulary, it causes them did not choose the correct answer in the ability test.

\section{CONCLUSION}

The result of data analysis shows that the mean score of the second year students of SMAN 1 Sikur in reading descriptive text is fairly good. There are $21(52.5 \%)$ students who were in a high position and $19(47.5 \%)$ students were in a low position. Although $52.5 \%$ of students in a high position and $47.5 \%$ in a low position, the students' mean score shown as low position, it was 7.2 mean score which classified as fairly good. So, the ability of the second year students of SMAN 1 Sikur has not been in a high position which is categorized from excellent to good score level. This is caused by the lack of reading strategy and vocabulary. The two weaknesses become students' difficulties in reading descriptive text. Therefore, the students did not get a maximal score in this investigation.

\section{ACKNOWLEDGMENT}

Praise be upon to Allah SWT, the Lord of the Universe, that under His blessing and great guidance, I eventually able to complete this article as one of the additional contributions in English Language Education. In accomplishing this article, I deservedly would like to acknowledge my deepest appreciation to all who have helped and supported me in accomplishing this article. Finally, I hope the readers could contribute to developmental criticism and suggestion in improving this article.

\section{REFERENCES}

Ambarini, R., Sumardiyani, L., \& Wardoyo, S. L. (2018). PACA (Predicting And Confirming Activity) Reading Strategies to Promote Students' Teaching Strategy in TEFL 1 Class. Celt: A Journal of Culture, English Language Teaching \& Literature, 18(1), 42. https://doi.org/10.24167/celt.v18i2.893

Arikunto, S. (2010). Prosedur Penelitian Suatu pendekatan Praktek. Jakarta: Rineka Cipta.

Aziz, Z. A., Nasir, C., \& Ramazani, R. (2019). Applying Metacognitive Strategies in Comprehending English Reading Texts. Celt: A Journal of Culture, English Language Teaching \& Literature, 19(1), 138. https://doi.org/10.24167/celt.v19i1.1863

Bolton, K. (2019). Braj B. Kachru and Asian Englishes. World Englishes, 38(1-2), 67-77. https://doi.org/10.1111/weng.12414

Haerazi, H., \& Irawan, L. A. (2020a). Developing Intercultural Language Learning (ILL) model to teach writing skills at Indonesian private universities. EduLite: Journal of English Education, Literature and Culture, 5(1), 43. https://doi.org/10.30659/e.5.1.43-54

Haerazi, H., May Vikasari, R., \& Prayati, Z. (2019). The Use of Scientific-Based Approach in ELT Class to Improve Students' Achievement and Classroom Interaction. Register Journal, 12(2), 157-180. https://doi.org/10.18326/rgt.v12i2.157-180

Haerazi, \& Irawan, L. A. (2020b). The effectiveness of ECOLA technique to improve reading comprehension in relation to motivation and self-efficacy. International Journal of Emerging Technologies in Learning, 15(1), 61-76. https://doi.org/10.3991/ijet.v15i01.11495

Hanifah, H., \& Afidah, N. (2018). Developing textbook by using reading strategic based instruction method for shariah economy department. JEES (Journal of English 
Educators Society), 3(2), 155. https://doi.org/10.21070/jees.v3i2.1552

Hartatik, Sri Fatmaning; Lestari, H. D. (2016). Reading experience non-native English speaking students majoring in English language teaching. JEES (Journal of English Educators Society), 1(October), 105-114. https://doi.org/10.21070/jees.v1i

Hidayat, N. (2017). Developing E-reading materials for students at grade sevent. JEES (Journal of English Educators Society), 2(1), 33. https://doi.org/10.21070/jees.v2i1.676

Imran, F., Firman, E., \& Raudhatunnisa, S. (2019). Applying Think-Talk-Write (Ttw) in the Teaching of Reading Comprehension in Relation To Students' Critical Thinking Skills. JOLLT Journal of Languages and Language Teaching, 7(1), 57. https://doi.org/10.33394/jollt.v7i1.1439

Indrasari, A., Novita, D., \& Megawati, F. (2018). Big Book: Attractive Media for Teaching Vocabulary to Lower Class of Young Learners. JEES (Journal of English Educators Society), 3(2), 141. https://doi.org/10.21070/jees.v3i2.1572

Khatimah, K., \& Rachman, D. (2018). Mind Mapping vs Semantic Mapping: Which Technique Gives EFL Learners more Benefits in Reading Comprehension? JEES $\begin{array}{lllll}\text { (Journal of English Educators } & \text { Society), } & 3(2), & \end{array}$ https://doi.org/10.21070/jees.v3i2.1498

Lail, H. (2019). Answering Reading Texts on English Tryout Test Based on the 12Th Grade Students' Strategies At Sma Negeri1 Kuripan Lombok Barat. JOLLT Journal of Languages and Language Teaching, 7(1), 3. https://doi.org/10.33394/jollt.v7i1.1434

Nerim, N. (2020). Scrutinizing Directed Reading thinking activity (DRTA ) Strategy on Students' Reading Comprehension. JOLLT Languages and Language Teaching, 8(2), 128-138. https://doi.org/10.33394/jollt.v8i2.2284

Rohmah, H. (2018). The Implementation of Herringbone Technique in Reading Comprehension at Second Semester of Non-English Department. Celt: A Journal of Culture, English Language Teaching \& Literature, 18(1), 59. https://doi.org/10.24167/celt.v18i1.555

Sugiyono. (2012). Metode Penelitian Kuantitatif Kualitatif dan R\&D. Bandung: Alfabeta.

Troyer, M., Kim, J. S., Hale, E., Wantchekon, K. A., \& Armstrong, C. (2019). Relations among intrinsic and extrinsic reading motivation, reading amount, and comprehension: a conceptual replication. Reading and Writing, 32(5), 1197-1218. https://doi.org/10.1007/s11145-018-9907-9 